\title{
APLIKASI MESIN BERKAS ELEKTRON UNTUK PENGOLAHAN GAS BUANG
}

\author{
Sudjatmoko \\ Pusat Teknologi Akselerator dan Proses Bahan - BATAN \\ Jl. Babarsari Kotak Pos 6101 Ykbb, Yogyakarta 55281
}

\begin{abstract}
ABSTRAK
APLIKASI MESIN BERKAS ELEKTRON UNTUK PENGOLAHAN GAS BUANG. Emisi gas buang $\mathrm{SO}_{2}$ dan $\mathrm{NO}_{x} \mathrm{ke}$ udara dari suatu aktivitas industri berat terutama dari pembakaran bahan bakar fosil seperti batubara dan minyak bumi pada pembangkit listrik merupakan salah satu sumber utama polusi lingkungan. Polutan udara tersebut seringkali berpindah tempat sampai ribuan kilometer dan menimbulkan masalah lingkungan di tempat lain, bahkan negara lain, oleh karena itu polusi udara tersebut menjadi masalah besar dunia. Pada saat ini beberapa negara telah menerapkan aturan pengendalian emisi yang lebih ketat untuk menyelesaikan masalah polusi udara. Pada saat ini pengolahan gas buang dengan berkas elektron diketahui sebagai suatu metode pengendalian polusi yang menjanjikan dengan beberapa keunggulan antara lain dapat mengolah $\mathrm{SO}_{2}$ dan $\mathrm{NO}_{x}$ secara serentak dengan tingkat efisiensi tinggi, merupakan proses kering, ramah lingkungan karena mengubah polutan menjadi pupuk pertanian dan lain sebagainya. Dalam makalah ini akan dibahas tentang Mesin Berkas Elektron dan aplikasinya untuk pengolahan gas buang PLTU batubara.
\end{abstract}

Kata Kunci : mesin berkas elektron, pengolahan gas buang, polusi lingkungan

\section{ABSTRACT}

THE APPLICATION OF ELECTRON BEAM MACHINE FOR FLUE GAS TREATMENT. The emission of environmental pollutant such as $\mathrm{SO}_{2}$ and $\mathrm{NO}_{x}$ into atmosphere from heavy industrial activities in particular from fossil fuel burning in electricity production has been recognized one of the main source of environmental pollution. These environmental pollutants sometimes travel more than thousand kilometers and make a trouble in other places, even in other countries, therefore the problem of the air pollution became world-wide problem. Now many countries are introducing more strict emission control regulations to solve the problem. Electron beam treatment of flue gas is now regarded as a promising pollution control method with some advantages: simultaneous reduction of $\mathrm{SO}_{2}$ and $\mathrm{NO}_{x}$ with high removal efficiency, being a dry process, yields a by-product with can be used as agriculture fertilizer, and so on. In this paper will be discussed concerning electron beam machine and its application for flue gas treatment produced from coal burning in the electric power station.

Key words : electron beam machine, flue gas treatment, environmental pollution

\section{PENDAHULUAN}

Emisi gas buang (flue gas) $\mathrm{SO}_{2}$ dan $\mathrm{NO}_{x}$ ke udara dari aktivitas industri berat, dan terutama dari pembakaran bahan bakar fosil seperti batubara dan minyak bumi pada pembangkit listrik merupakan salah satu sumber polusi dalam skala besar. Reaksi yang terjadi di udara akan menyebabkan hujan asam yang berbahaya bagi lingkungan. Keadaan ini diperparah dengan meningkatnya penggunaan batubara berkualitas rendah yang mengandung kadar belerang tinggi.

Dampak terhadap lingkungan hidup berkaitan dengan kebutuhan dan ketersediaan energi menjadi faktor penting yang mempengaruhi pengembangan dan penggunaan energi secara komersial, serta teknologi pengendalian emisi gas buang; karena pembangkitan energi melibatkan masalah penyebaran polusi udara yang dapat melintasi batas antar negara, diperlukan strategi dan kebijakan yang terkoordinasi secara internasional untuk pengendalian emisi gas buang $\mathrm{SO}_{2}$ dan $\mathrm{NO}_{x}$.

Emisi polutan dari gas buang ditentukan oleh kebutuhan dan ketersediaan energi serta adanya pembuatan undang-undang pengendalian emisi, dan terutama jenis bahan bakar yang digunakan memiliki pengaruh yang besar pada emisi. Hal ini ditunjukkan oleh jangkau emisi yang lebar per satuan kualitas bahan bakar yang berbeda; sebagai contoh: emisi $\mathrm{SO}_{2}$ yang tak terkendali dari pembakaran batubara dapat bervariasi antara $550 \mathrm{mg} /$ $\mathrm{m}^{3}-5.800 \mathrm{mg} / \mathrm{m}^{3}$, sedangkan untuk pembakaran minyak ringan dan minyak berat emisi $\mathrm{SO}_{2}$ antara $125 \mathrm{mg} / \mathrm{m}^{3}$ - 
$1.300 \mathrm{mg} / \mathrm{m}^{3}$, dan pembakaran gas antara $0 \mathrm{mg} / \mathrm{m}^{3}-25 \mathrm{mg} / \mathrm{m}^{3}$. Emisi $\mathrm{NO}_{\mathrm{x}}$ dapat bervariasi antara $300 \mathrm{mg} / \mathrm{m}^{3}$ untuk gas alam dan $1.800 \mathrm{mg} / \mathrm{m}^{3}$ untuk batubara di bagian bawah boiler yang lembab ${ }^{[1]}$.

Berbagai negara telah menetapkan batas emisi yang bergantung pada situasi dan kondisi masing-masing negara, dimana batas emisi tersebut dapat bergantung pada jenis pembangkit energi (baru atau lama), besarnya sistem pembangkit energi dan bahan bakar yang digunakan. Batas emisi dari setiap negara bervariasi, sebagai contoh: di Austria $200 \mathrm{mg} / \mathrm{m}^{3} \mathrm{SO}_{2}$ dan di Australia $2.000 \mathrm{mg} / \mathrm{m}^{3} \mathrm{SO}_{2}$ untuk pembangkit energi yang sama. Sejumlah negara telah menetapkan batas emisi polutan dari gas buang, namun hasil emisi tidak selalu memenuhi batas yang ditetapkan. Hal ini mendorong usaha untuk mendapatkan solusi yang murah guna mengendalikan kelebihan emisi $\mathrm{SO}_{2}$ dan $\mathrm{NO}_{x}$.

Ada beberapa teknologi dan proses yang telah dikembangkan untuk mengurangi emisi $\mathrm{SO}_{2}$ dan $\mathrm{NO}_{x}$, diantaranya adalah FGD (Flue Gas Desulphurisation) dan SCR (Selective Catalitic Reduction). Teknologi konvensional FGD untuk $\mathrm{SO}_{2}$ dan $\mathrm{SCR}$ untuk $\mathrm{NO}_{x}$ telah dimanfaatkan secara luas di berbagai negara maju, namun teknologi tersebut masih terlampau mahal dan penerapannya memerlukan lahan yang luas. Suatu teknologi baru yang mulai diterapkan dalam skala industri adalah proses pembersihan gas buang $\mathrm{SO}_{2}$ dan $\mathrm{NO}_{x}$ dengan mesin berkas elektron (MBE) yang dapat mengurangi kadar polutan gas buang sampai batas ambang aman untuk lingkungan. Proses pengolahan gas buang menggunakan MBE mempunyai beberapa kelebihan dibandingkan dengan proses konvensional (FGD dan SCR) antara lain: merupakan satu sistem proses yang kompak karena dapat mengolah $\mathrm{SO}_{2}$ dan $\mathrm{NO}_{x}$ secara serentak dengan tingkat efisiensi tinggi, sangat cocok untuk pengolahan gas buang dengan kandungan $\mathrm{SO}_{2}$ yang tinggi dan membutuhkan air proses sedikit dibandingkan dengan $\mathrm{FGD}$, ramah lingkungan karena proses akan mengubah polutan menjadi pupuk pertanian dan tidak menghasilkan limbah/polutan baru, lebih ekonomis ditinjau dari segi konstruksi dan operasi instalasi, serta pengaruh terhadap biaya produksi tenaga listrik relatif kecil bahkan ada kemungkinan berubah menjadi keuntungan bila pupuk dapat dikelola dengan baik, serta lahan yang dibutuhkan untuk instalasi relatif lebih kecil dibandingkan dengan teknologi sejenis yang lain.

Dalam makalah ini akan disajikan tentang deskripsi MBE untuk pengolahan gas buang, dan dibahas pengaruh suhu gas buang, besarnya dosis, daya berkas dan energi berkas elektron terhadap removal efficiency $\mathrm{SO}_{2}$ dan $\mathrm{NO}_{x}$. Diharapkan dengan hasil pembahasan tersebut dapat memberikan sumbangan dalam persiapan pelaksanaan Sasaran Utama BATAN tentang "Engineering Design Demonstration Plant Mesin Berkas Elektron Untuk De-SO x dan De-NO O PLTU Batubara” yang diharapkan dapat diselesaikan pada akhir tahun 2007.

\section{DESKRIPSI MBE UNTUK PENGOLAHAN GAS BUANG}

Teknologi MBE untuk pengolahan gas buang $\mathrm{SO}_{2}$ dan $\mathrm{NO}_{x}$ pada umumnya terdiri dari lima komponen utama, yaitu ${ }^{[2]}$ :

1. Spray cooler

2. Sistem injeksi amonia

3. Sistem iradiasi : bejana proses dan mesin berkas elektron

4. Sistem pengumpul produk samping

5. Sistem instrumentasi dan kendali

Apabila proses pengolahan gas buang menggunakan berkas elektron untuk membersihkan gas buang dari boiler suatu pembangkit listrik, gas buang pertama kali harus dibersihkan dari abu-layang menggunakan kolektor partikel yang biasa disebut ESP (Electrostatic Precipitator). Selanjutnya gas buang dilewatkan pada evaporative spray cooler dimana suhu gas buang diturunkan ketika humidity meningkat, kemudian gas buang sebelum masuk ke dalam bejana proses (process vessel) diinjeksikan sejumlah amonia. Di dalam bejana proses gas buang diradiasi dengan berkas elektron energi tinggi, $\mathrm{SO}_{2}$ dan $\mathrm{NO}_{x}$ teroksidasi masing-masing membentuk $\mathrm{H}_{2} \mathrm{SO}_{4}$ dan $\mathrm{HNO}_{3}$, dan selanjutnya asam sulfat dan asam nitrat tersebut bereaksi dengan amonia yang diinjeksikan membentuk amonium sulfat dan amonium sulfat-nitrat. Garam-garam tersebut selanjutnya diproses menjadi serbuk kering menggunakan suatu kolektor partikel konvensional (dry ESP), dan serbuk kering yang terkumpul dapat dijual sebagai pupuk pertanian. 
Fasilitas MBE yang digunakan untuk pengolahan gas buang $\mathrm{SO}_{2}$ dan $\mathrm{NO}_{x}$ terdiri dari beberapa komponen yang dijelaskan seperti tersebut di bawah ini, dan skema proses berkas elektron untuk pengolahan gas buang dapat dilihat dalam Gambar 1.

\section{ESP (Electrostatic Precipitator)}

Perlakuan awal gas buang sebelum memasuki proses pengolahan menggunakan MBE, gas buang dari sistem pembangkit energi yang mengandung particulates, $\mathrm{SO}_{2}$ dan $\mathrm{NO}_{x}$ dilewatkan pada suatu ESP untuk membersihkan abu-layang.

\section{Sistem spray cooler}

Gas buang setelah melewati ESP pada suhu sekitar $125^{\circ} \mathrm{C}$ selanjutnya masuk ke dalam evaporative spray cooler untuk mencapai suhu sekitar $65^{\circ} \mathrm{C}$ (suhu proses) dalam suatu pendinginan adiabatik dengan kandungan uap air hingga $11,5 \%$ dalam volume gas buang. Kabut air diinjeksikan ke dalam aliran gas buang dan pada setiap spray cooler menggunakan single fluid water nozzles dengan pompa hidraulik.

\section{Sistem injeksi amonia}

Setelah melewati sistem spray cooler, gas buang mengalir ke dalam bejana iradiasi. Pada sisi masuk dari bejana iradiasi, gas amonia diinjeksikan ke dalam gas buang. Amonia disimpan dalam suatu tangki penyimpanan yang terletak di dalam suatu gedung tersendiri. Pada saat diinjeksikan amonia diuapkan menggunakan pemanasan listrik, dan agar supaya terdistribusi dengan baik ke dalam gas buang, maka amonia didistribusikan menggunakan multi-nozzle assembly.

\section{Sistem iradiasi}

Di dalam bejana proses, gas buang yang mengandung $\mathrm{SO}_{2}, \mathrm{NO}_{x}$ dan amonia diiradiasi dengan berkas elektron energi tinggi dari MBE yang dipasang di atas bejana proses dan tegak lurus dengan aliran gas buang. Dosis radiasi dipilih dalam jangkau 0 8 kGy untuk mendapatkan removal efficiency $\mathrm{SO}_{2} \approx 90 \%$ dan removal efficiency $\mathrm{NO}_{x} \approx 55 \%$, sedangkan parameter lainnya: energi elektron $0,6 \sim 0,9 \mathrm{MeV}$, arus berkas maksimum 110 $\mathrm{mA}$, daya berkas elektron $90 \mathrm{~kW}$, efisiensi energi $70 \%$ dan laju aliran gas buang $20.000 \mathrm{Nm}^{3} / \mathrm{jam}$. Fasilitas MBE ditempatkan di dalam ruangan dengan struktur beton sebagai sistem perisai radiasi agar supaya tidak ada radiasi yang diemisikan ke lingkungan di sekitarnya.

\section{Sistem pengumpul produk samping}

Gas buang setelah melewati sistem iradiasi dilewatkan ke dalam sistem pengumpul produk samping (byproduct collection system) berupa dry ESP yang berfungsi menangkap produk samping dengan emisi partikulat kurang dari $30 \mathrm{mg} / \mathrm{Nm}^{3}$. Pada umumnya produk samping tersebut terdiri dari amonium sulfat $88 \%$, amonium nitrat 10 dan abu-layang $2 \%$.

\section{Sistem instrumentasi dan kendali}

Sistem instrumentasi dan kendali (SIK) dalam teknologi MBE memegang peranan penting pada saat pengoperasian MBE. Sistem interlock harus memenuhi keperluan keselamatan, terutama pada fungsi pengendalian dan operasi, dan juga untuk melindungi setiap komponen dan instalasi MBE terhadap kesalahan sistem mekanik dan listrik. SIK berfungsi:

- Pemeriksaan initial data secara otomatik terhadap data entry dan memperkecil kesalahan operator

- Otomatisasi prosedur start up dan shut down

- Otomatisasi fungsi pengamatan dan kendali setiap parameter kritis

- Mempermudah dan memperbaiki kendali proses

- Otomatisasi pengkondisian

- Data logging dan graphic display 


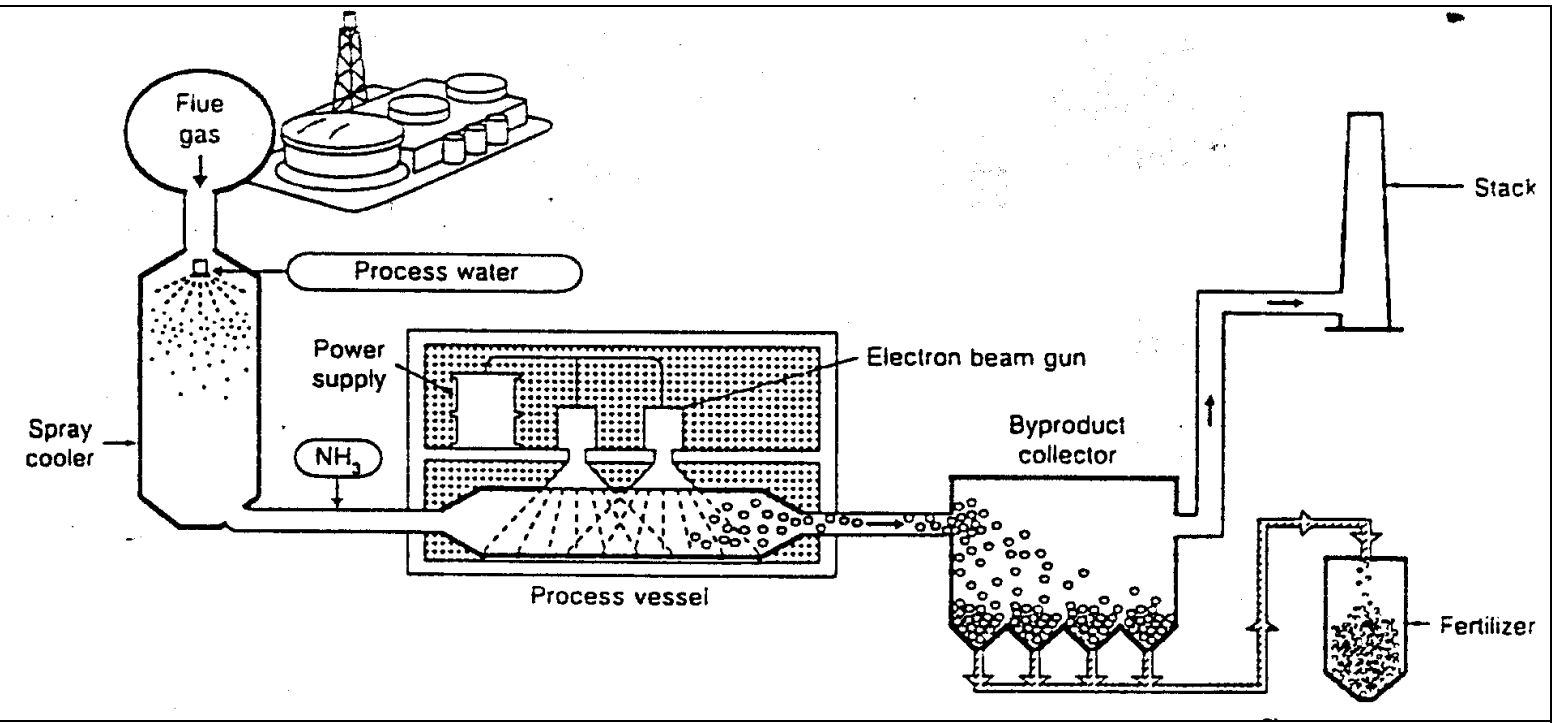

Gambar 1. Skema proses berkas elektron untuk pengolahan gas buang (2).

\section{PEMBAHASAN}

Proses pengolahan gas buang menggunakan MBE adalah proses pengolahan kering gas buang menggunakan berkas elektron yang secara simultan dapat mereduksi $\mathrm{SO}_{2}$ dan $\mathrm{NO}_{x}$. Iradiasi gas buang menghasilkan radikal-radikal aktif yang bereaksi dengan $\mathrm{SO}_{2}$ dan $\mathrm{NO}_{x}$ membentuk asam sulfat dan asam nitrat. Dengan penambahan amonia $\left(\mathrm{NH}_{3}\right)$, asam sulfat dan asam nitrat akan berubah menjadi amonium sulfat $\left(\mathrm{NH}_{4}\right)_{2} \mathrm{SO}_{4}$ dan amonium sulfat-nitrat $\left(\mathrm{NH}_{4}\right)_{2} \mathrm{SO}_{4} \cdot 2 \mathrm{NH}_{4} \mathrm{NO}_{3}$. Prinsip proses pengolahan gas buang dengan MBE ditampilkan dalam Gambar 2 di bawah ini.

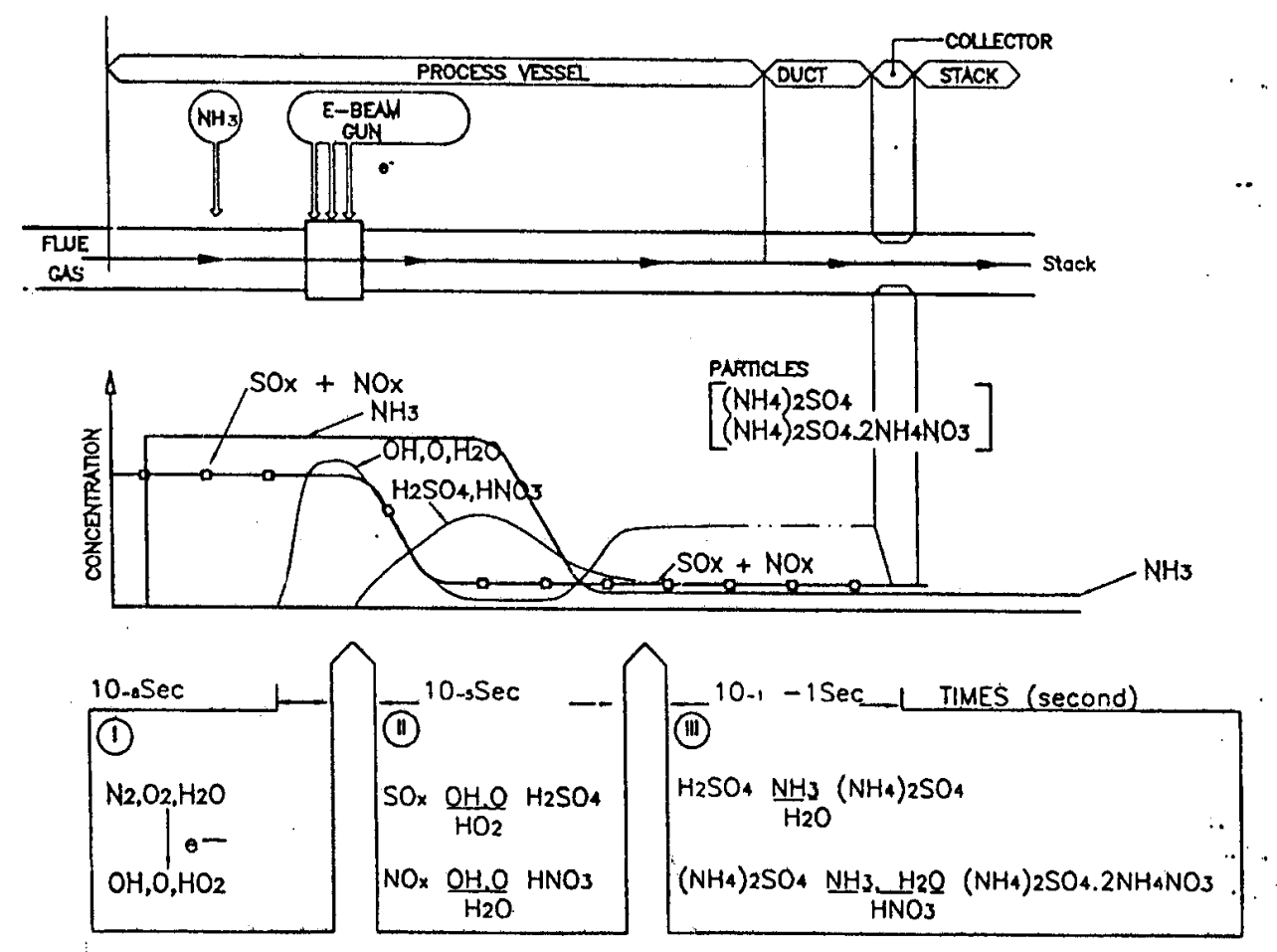

Gambar 2. Prinsip proses pengolahan gas buang dengan MBE 
Apabila iradiasi berkas elektron digunakan dalam proses untuk membersihkan gas buang dari suatu boiler sistem pembangkit listrik, gas buang pertama kali harus dibersihkan dari abu-layang dengan menggunakan ESP (Dry Electrostatic Precipitator). Kemudian gas buang dilewatkan pada suatu sistem evaporative spray cooler sehingga terjadi penurunan suhu gas buang ketika kelembabannya meningkat. Gas buang yang telah diinjeksi dengan gas amonia kemudian dilewatkan pada bejana proses untuk diiradiasi dengan berkas elektron energi tinggi. Dalam gas buang $\mathrm{SO}_{2}$ dan $\mathrm{NO}_{x}$ teroksidasi dan masing-masing membentuk $\mathrm{H}_{2} \mathrm{SO}_{4}$ dan $\mathrm{HNO}_{3}$, kemudian secara berurutan bereaksi dengan amonia yang diinjeksikan membentuk amonium sulfat dan amonium sulfatnitrat. Garam-garam tersebut diproses menjadi bubuk kering (dry powder) menggunakan sistem pengumpul produk samping (by-product collection system). Bubuk kering yang terkumpul tersebut dapat dimanfaatkan sebagai bahan pupuk pertanian.

Jumlah $\mathrm{SO}_{2}$ dan $\mathrm{NO}_{x}$ dalam gas buang yang dapat direduksi (removal efficiency) setelah proses iradiasi berkas elektron dipengaruhi oleh beberapa parameter yang berbeda, antara lain adalah suhu dan kelembaban gas buang, dosis terserap, konsentrasi awal $\mathrm{NO}_{x}$, energi dan daya berkas elektron. Ada dua proses yang mengakibatkan terjadinya reduksi $\mathrm{SO}_{2}$, yang pertama adalah proses kimia yang juga disebut reaksi termal (thermal reaction) dan kedua adalah reaksi akibat radiasi (radiation-induced reaction), yang sangat bergantung pada suhu dan kelembaban gas buang ${ }^{[3]}$ :

$$
\eta_{s 02}=f_{1}(\varphi, \alpha, T)+f_{2}(D, \alpha, T)
$$

dimana : $\eta_{\mathrm{so} 2}$ adalah removal efficiency $\mathrm{SO}_{2}(\%)$

$a$ adalah amonia stoichiometri

$T$ adalah suhu gas buang $(\mathrm{K})$.

Sedangkan removal efficiency $\mathrm{NO}_{x}$ bergantung terutama pada dosis ${ }^{[3]}$ :

$$
\eta_{N O X}=\Delta N O_{x} /\left(N O_{x}\right)_{0}=k_{1}\left[1-\exp \left(k_{2} D /\left(N O_{x}\right)_{0}\right)\right]
$$

dimana: $\left(\mathrm{NO}_{\mathrm{x}}\right)_{0}$ adalah konsentrasi saat masuk (ppm)

$D$ adalah dosis ( $\mathrm{KGy})$

$k_{1}$ dan $k_{2}$ adalah konstante empiris.

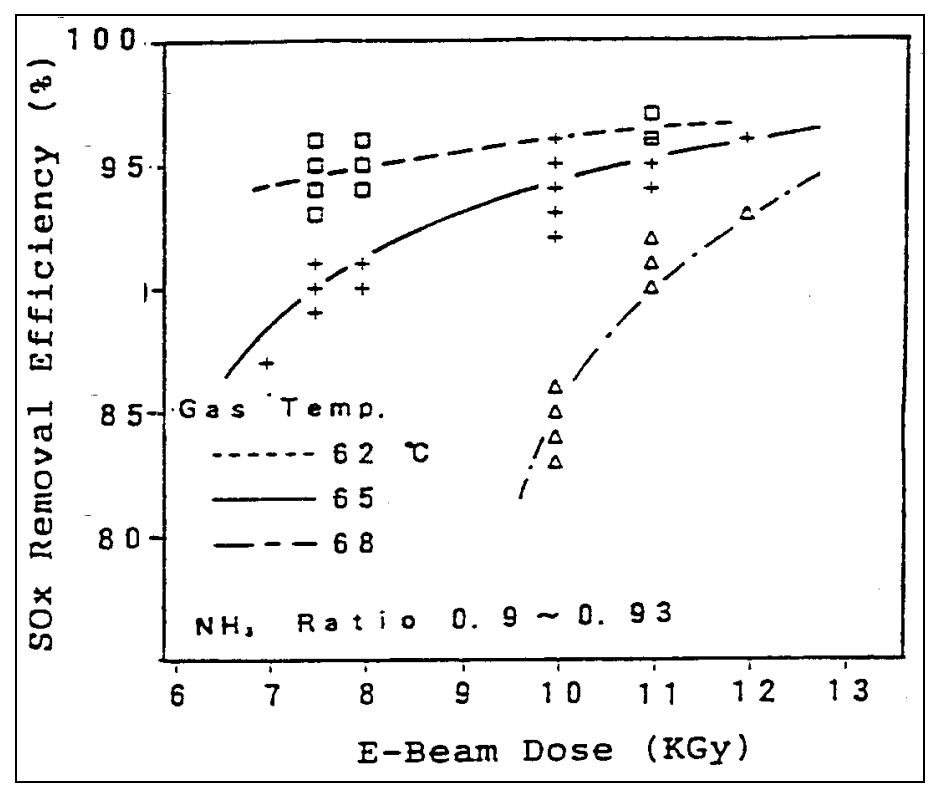

Gambar 3. Hubungan antara dosis dengan removal efficiency $\mathrm{SO}_{2}{ }^{[4]}$

Pemilihan kondisi proses yang tepat (kelembaban gas $10-15 \%$ vol, suhu gas $60-70{ }^{\circ} \mathrm{C}$ ) akan menghasilkan removal efficiency $\mathrm{SO}_{2}$ yang tinggi pada pemakaian energi yang rendah. Kira-kira $70 \%$ reduksi $\mathrm{SO}_{2}$ 
berasal dari reaksi termokimia dan tambahan 20 - 25\% dihasilkan dari proses akibat radiasi. Gambar 3 menyajikan hubungan antara dosis terserap dan removal efficiency $\mathrm{SO}_{2}$ dengan beberapa variasi suhu gas ${ }^{[4,5]}$. Removal efficiency sangat bergantung pada suhu gas buang yang diproses. Pada suhu gas buang semakin rendah akan dicapai removal efficiency $\mathrm{SO}_{2}$ yang lebih tinggi. Nilai dosis terhadap reduksi $\mathrm{SO}_{2}$ menjadi kurang berarti dalam daerah suhu gas buang yang semakin rendah. Kecenderungan ini diakibatkan oleh efek reaksi termal ${ }^{[6]}$.

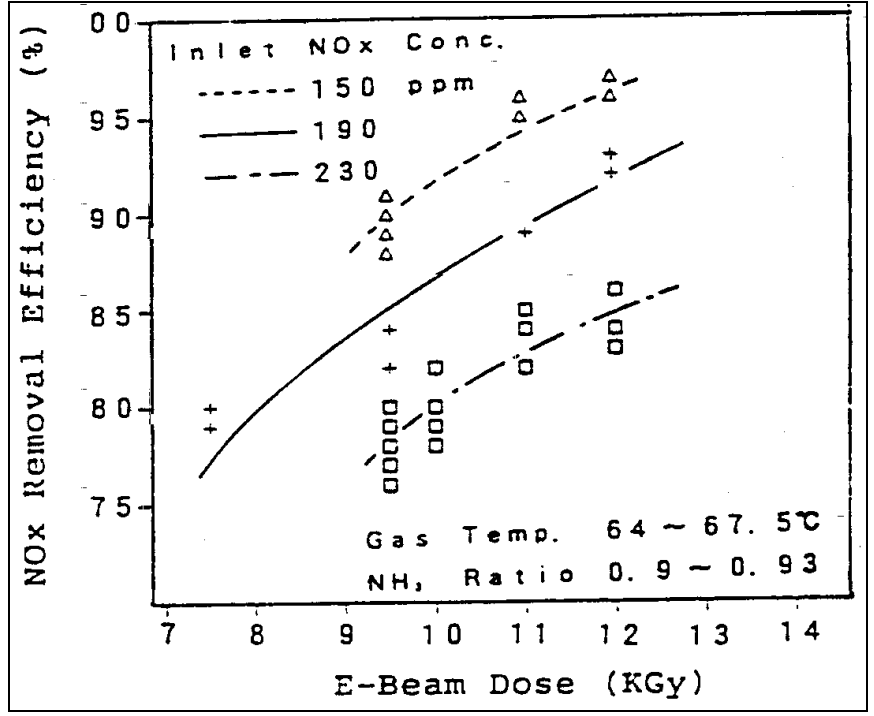

Gambar 4. Hubungan antara dosis removal efficiency $\mathrm{NO}_{x}{ }^{[4]}$

Removal efficiency $\mathrm{NO}_{x}$ sangat bergantung pada nilai dosis seperti terlihat dalam rumus (2) di atas. Gambar 4 menyajikan hubungan antara dosis terserap dan removal efficiency $\mathrm{NO}_{x}$ untuk beberapa konsentrasi $\mathrm{NO}_{x}$ yang masuk. Dengan bertambahnya

konsentrasi $\mathrm{NO}_{x}$ yang masuk maka removal efficiency $\mathrm{NO}_{x}$ berkurang. Reduksi $\mathrm{NO}_{x}$ diakibatkan oleh reaksi dengan radikal-radikal yang dihasilkan oleh iradiasi elektron.

Pada Gambar 5 disajikan removal efficiency $\mathrm{NO}_{x}$ dan $\mathrm{SO}_{2}$ versus dosis untuk nilai konsentrasi $\mathrm{SO}_{2}, \mathrm{NO}_{x}$ dan suhu gas tertentu. Karena reaksi termal yang terjadi maka removal efficiency $\mathrm{SO}_{2}$ sangat bergantung pada suhu gas buang dan hanya diperlukan dosis yang rendah untuk mendapatkan removal efficiency $\mathrm{SO}_{2}$ yang tinggi, dan kemudian nilainya konstan sekitar $98 \%$ meskipun nilai dosis semakin besar. Removal efficiency $\mathrm{NO}_{\mathrm{x}}$ sangat bergantung pada nilai dosis, dan pada dosis 4 kGy dihasilkan removal efficiency $\mathrm{NO}_{x}$ hanya sekitar $48 \%$ sedangkan removal efficiency $\mathrm{SO}_{2}$ telah mencapai $98 \%$. Pada Gambar 6 ditampilkan data removal efficiency $\mathrm{SO}_{2}$ dan $\mathrm{NO}_{x}$ dari Kaweczyn Pilot Plant di Polandia saat beroperasi untuk kondisi operasi: kelembaban gas buang $15 \%$ vol dan suhu $45{ }^{\circ} \mathrm{C}$, daya berkas elektron sekitar $60 \mathrm{~kW}$. Di bawah kondisi operasi tersebut removal efficiency $\mathrm{SO}_{2} 98 \%$ dan $\mathrm{NO}_{x}$ sekitar $70 \%$ dapat dicapai ${ }^{[3]}$.

Dalam teknologi pengolahan gas buang menggunakan MBE, parameter energi elektron $E(M e V)$ dan daya berkas elektron $\mathrm{P}(\mathrm{kW})$ merupakan faktor penting untuk ditentukan. Daya berkas elektron yang diperlukan dalam suatu instalasi MBE untuk pengolahan gas buang dapat ditentukan dengan rumusan ${ }^{\left[{ }^{[7]}\right.}$ :

$$
P(k W)=\frac{M(\mathrm{~kg} / \mathrm{jam}) \times D(k G y)}{3.600 \eta}
$$

dengan $P$ adalah daya berkas elektron

$M$ adalah massa gas buang yang akan diproses

$D$ adalah dosis terserap

$\eta$ adalah koefisien penggunaan iradiasi 


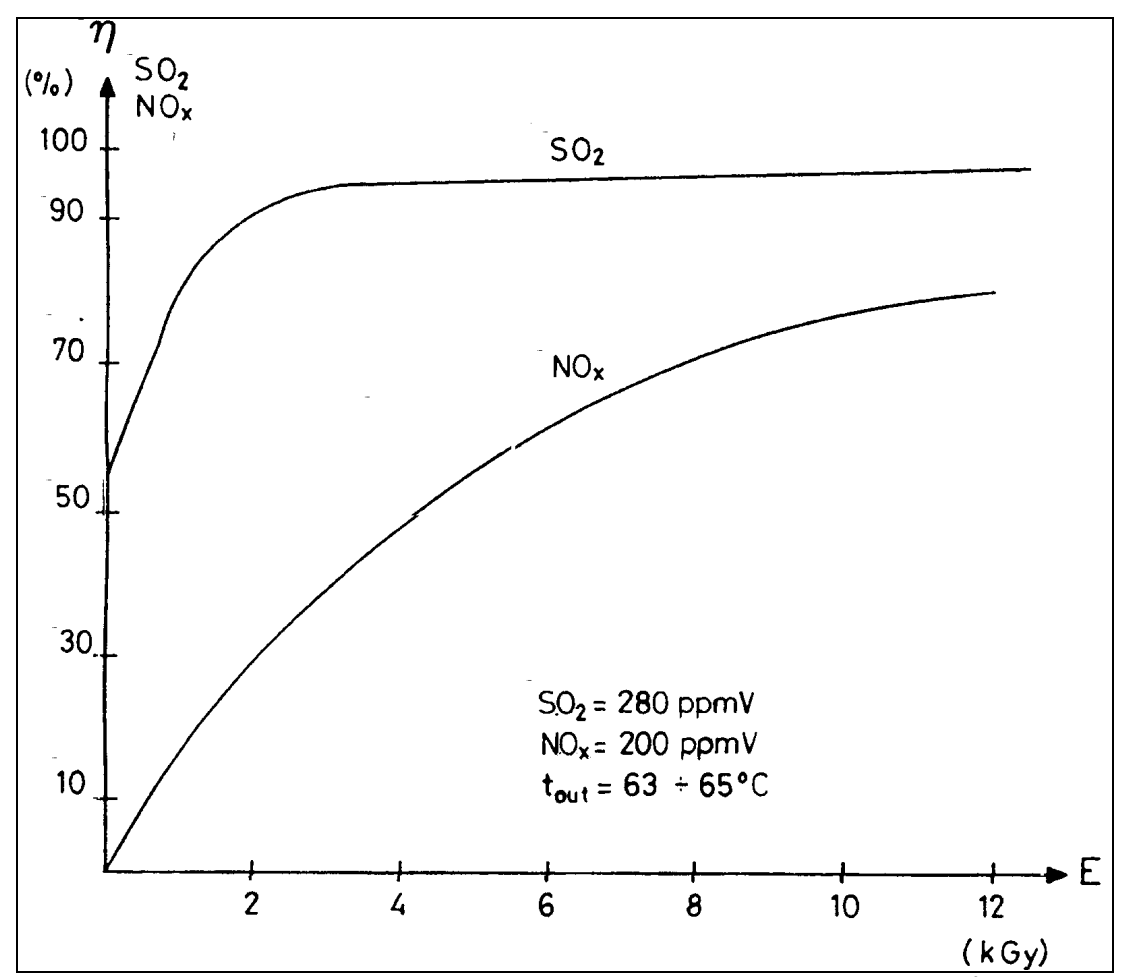

Gambar 5. Removal efficiency $\mathrm{NO}_{x}$ dan $\mathrm{SO}_{2}$ versus dosis ${ }^{[3]}$

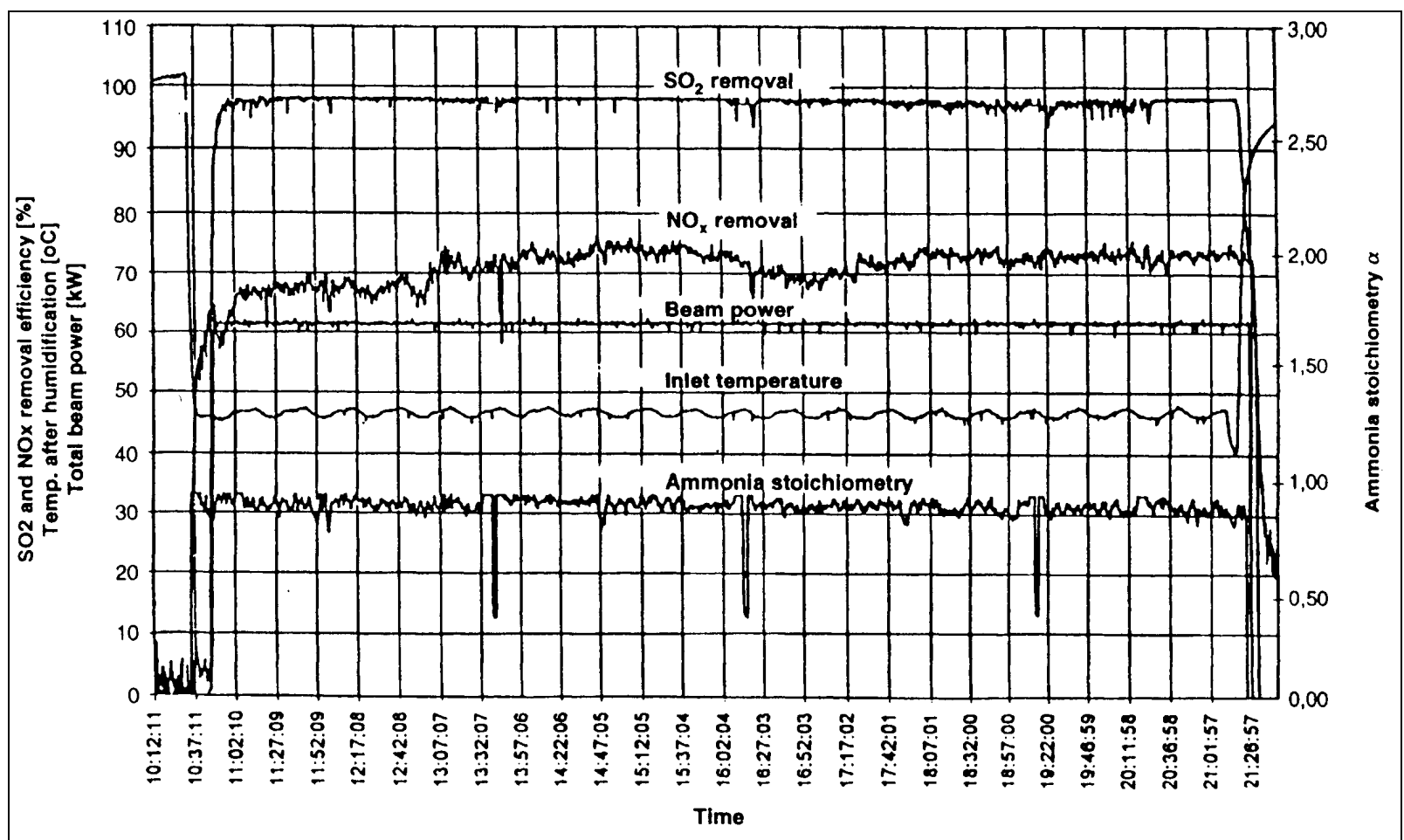

Gambar 6. Removal efficiency $\mathrm{SO}_{2}$ dan $\mathrm{NO}_{x}$ pada kondisi operasi suhu gas buang $45^{\circ} \mathrm{C}$ dan daya berkas $60 \mathrm{~kW}^{[3]}$. 


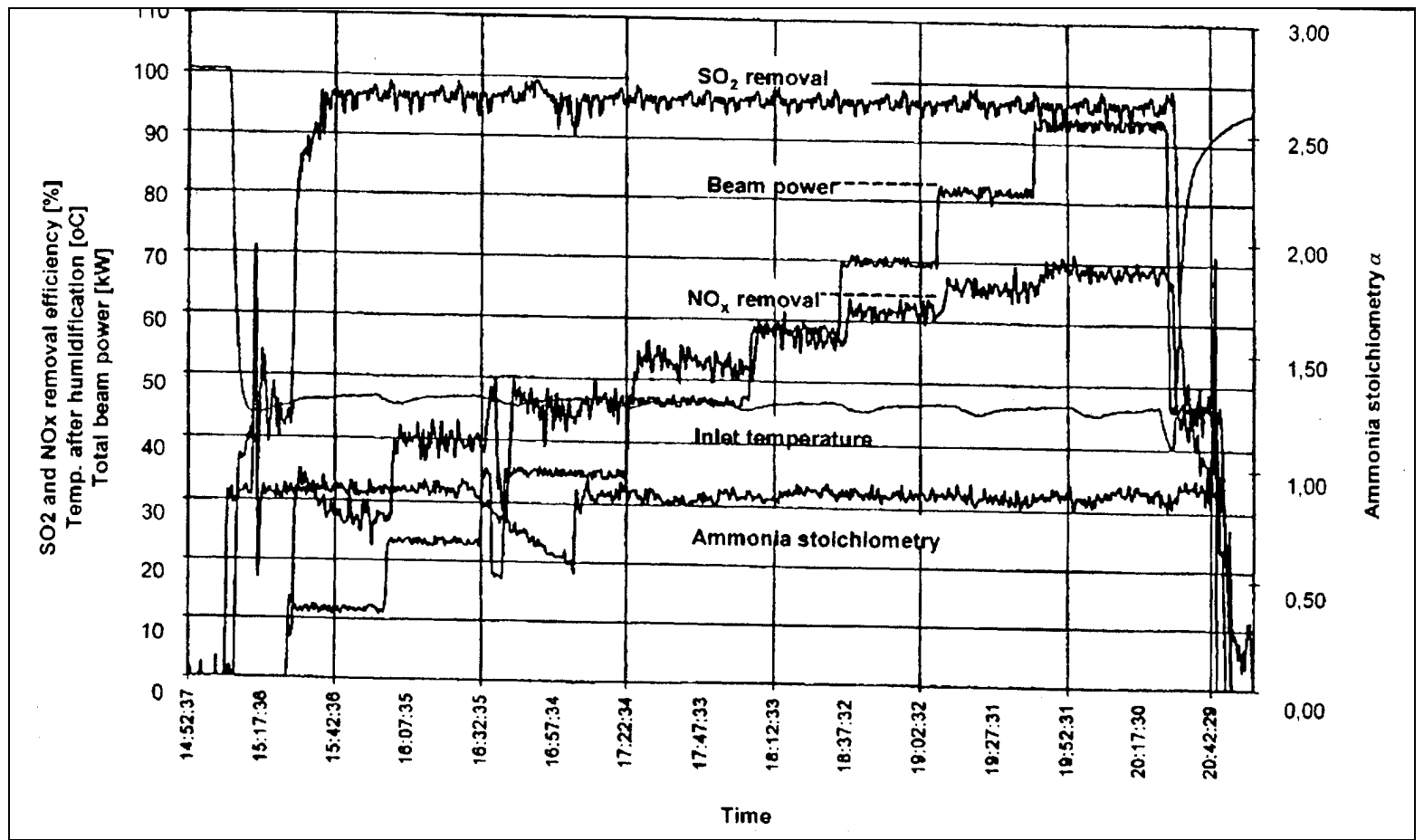

Gambar 7. Pengaruh daya berkas elektron terhadap removal efficiency $\mathrm{SO}_{2}$ dan $\mathrm{NO}_{x}$ pada suhu gas buang $45^{\circ} \mathrm{C}{ }^{[3]}$.

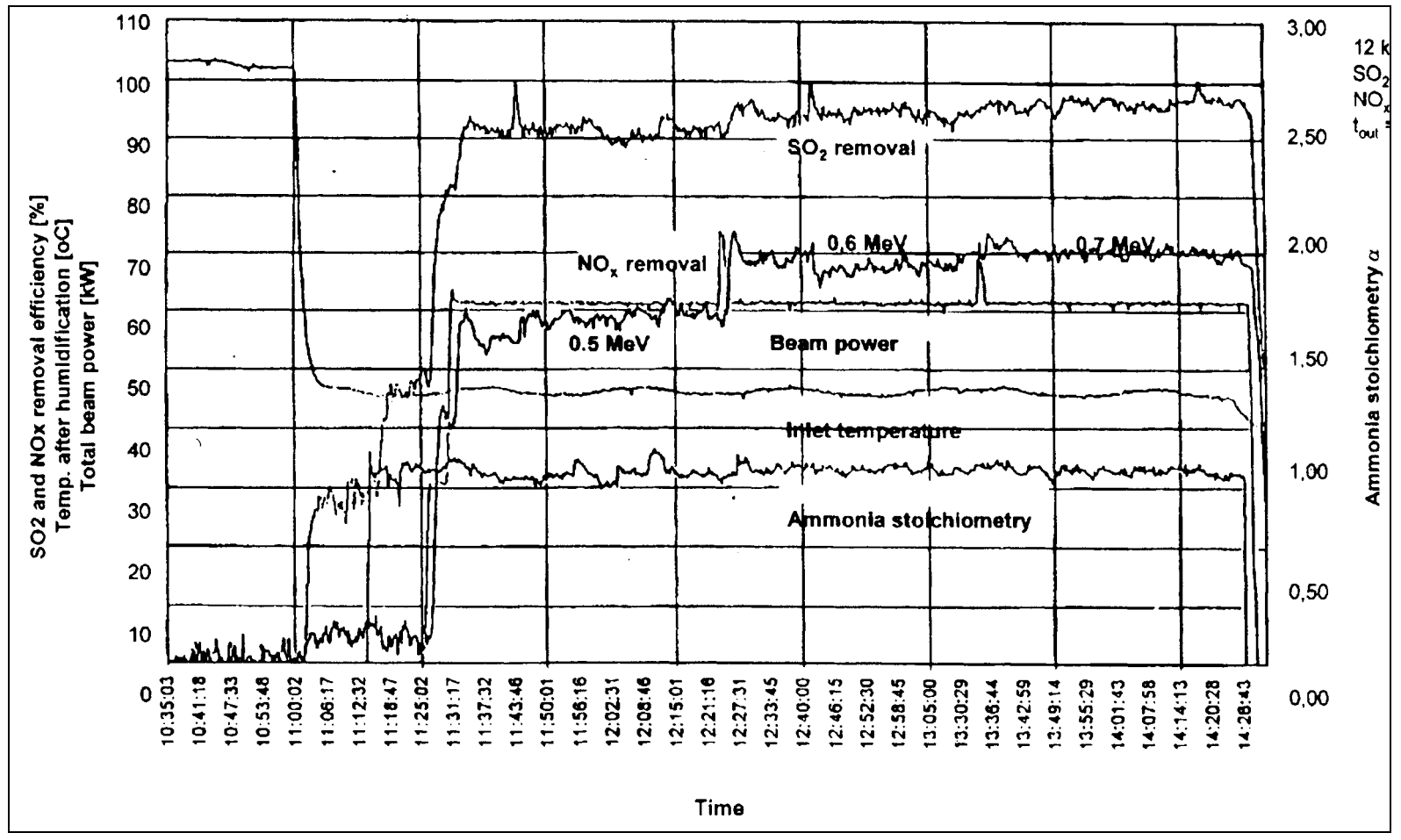

Gambar 8. Removal efficiency $\mathrm{SO}_{2}$ dan $\mathrm{NO}_{\mathrm{x}}$ untuk beberapa nilai energi berkas elektron yang berbeda ${ }^{[3]}$. 
Dalam Gambar 7 ditampilkan pengaruh daya berkas elektron terhadap removal efficiency $\mathrm{SO}_{2}$ dan $\mathrm{NO}_{x}$ pada suhu gas buang $45{ }^{\circ} \mathrm{C}$ dan nilai konsentrasi masukan $\mathrm{NO}_{x}$ tertentu, terlihat bahwa removal efficiency $\mathrm{SO}_{2}$ tidak terpengaruh dan hanya dipengaruhi oleh suhu gas buang. Sedangkan daya berkas elektron cukup mempengaruhi nilai removal efficiency $\mathrm{NO}_{x}$, dan ini sesuai dengan rumusan pada persamaan (3), dimana dosis yang diberikan sebagai fungsi dari daya berkas elektron dan juga massa gas buang yang mengadung $\mathrm{NO}_{\mathrm{x}}$, dan mencapai nilai optimum $70 \%$ pada saat nilai daya berkas elektron sekitar $70 \mathrm{~kW}$.

Besarnya energi elektron setelah mengalami percepatan di dalam MBE sangat menentukan kedalaman penetrasi pada obyek yang diiradiasi, dalam hal ini adalah gas buang. Kedalaman penetrasi elektron tersebut dapat dituliskan sebagai berikut ${ }^{[7]}$ :

$$
\Delta(\mathrm{cm})=\frac{0,33 E(\mathrm{MeV})}{\rho\left(\mathrm{g} / \mathrm{cm}^{2}\right)}
$$

dengan : $\Delta$ adalah kedalaman penetrasi elektron dalam bahan

$E$ adalah energi elektron

$\rho$ adalah rapat jenis bahan

Dalam Gambar 8 ditampilkan removal efficiency $\mathrm{SO}_{2}$ dan $\mathrm{NO}_{x}$ untuk beberapa nilai energi berkas elektron yang berbeda, dan terlihat bahwa removal efficiency $\mathrm{SO}_{2}$ tidak terpengaruh oleh perubahan energi elektron terutama karena reduksi $\mathrm{SO}_{2}$ hanya diakibatkan oleh efek reaksi termal yang dipengaruhi oleh suhu gas buang; sedangkan perubahan energi elektron ada pengaruhnya pada nilai removal efficiency $\mathrm{NO}_{\mathrm{x}}$. Energi berkas elektron yang hilang dipindahkan ke gas buang terdiri dari dua komponen utama : pertama adalah daya henti dari jendela titanium dan celah udara di antara keping titanium dalam scanning horn, dan kedua karena serapan dalam bejana reaksi yang berisi gas buang yang diiradiasi. Untuk elektron dengan energi rendah maka energi yang hilang dalam sistem jendela scanning horn sangat tinggi; sebaliknya untuk elektron dengan energi tinggi maka energi yang diserap oleh dinding bejana reaksi menjadi lebih besar. Oleh karena itu energi optimum elektron dapat diberikan oleh rancangan bejana reaksi, dan nilai removal efficiency $\mathrm{NO}_{x}$ tertinggi dapat tercapai pada energi elektron optimum yang besarnya sekitar $0,70 \mathrm{MeV}$.

\section{KESIMPULAN}

Berdasarkan pembahasan tersebut di atas dapat diambil beberapa kesimpulan sebagai berikut :

Proses pengolahan gas buang menggunakan MBE adalah proses pengolahan kering gas buang menggunakan berkas elektron yang secara simultan dapat mereduksi $\mathrm{SO}_{2}$ dan $\mathrm{NO}_{x}$. Iradiasi gas buang menghasilkan radikal-radikal aktif yang bereaksi dengan $\mathrm{SO}_{2}$ dan $\mathrm{NO}_{x}$ membentuk asam sulfat dan asam nitrat. Dengan penambahan amonia $\left(\mathrm{NH}_{3}\right)$, asam sulfat dan asam nitrat akan berubah menjadi amonium sulfat $\left(\mathrm{NH}_{4}\right)_{2} \mathrm{SO}_{4}$ dan amonium sulfat-nitrat $\left(\mathrm{NH}_{4}\right)_{2} \mathrm{SO}_{4} \cdot 2 \mathrm{NH}_{4} \mathrm{NO}_{3}$. Garam-garam tersebut diproses menjadi bubuk kering (dry powder) menggunakan sistem pengumpul produk samping (by-product collection system). Bubuk kering yang terkumpul tersebut dapat dimanfaatkan sebagai bahan pupuk pertanian.

Removal efficiency $\mathrm{SO}_{2}$ sangat bergantung pada suhu gas buang yang diproses, pada suhu yang semakin rendah akan diperoleh removal efficiency yang semakin besar. Nilai removal efficiency $\mathrm{SO}_{2}$ terhadap dosis menjadi kurang berarti pada daerah suhu gas buang yang semakin rendah, dan kecenderungan ini diakibatkan oleh efek reaksi termal.

Removal efficiency $\mathrm{NO}_{\mathrm{x}}$ sangat bergantung pada dosis yang diberikan dan juga ada kaitannya dengan konsentrasi $\mathrm{NO}_{x}$ yang masuk. Dengan meningkatnya konsentrasi $\mathrm{NO}_{\mathrm{x}}$ yang masuk, maka removal efficiency $\mathrm{NO}_{\mathrm{x}}$ akan menurun. Reduksi $\mathrm{NO}_{x}$ ini diakibatkan oleh reaksi dengan radikal-radikal yang dihasilkan oleh radiasi pengion.

Daya berkas energi berkas elektron mempunyai pengaruh terutama pada nilai removal efficiency dari $\mathrm{NO}_{\mathrm{x}}$, oleh karena itu dalam perencanaan pemakaian MBE untuk pengolahan gas buang perlu dimasukkan optimasi nilai daya berkas dan energi elektron. Hal ini perlu dipertimbangkan karena semakin besar daya berkas dan energi elektron berkaitan dengan semakin mahalnya harga MBE yang akan digunakan. 


\section{DAFTAR PUSTAKA}

1. CHMIELEWSKI A.G., ILLER E., TYMINSKI B., ZIMEK Z., Industrial Implementation of Electron Beam Flue Gas Treatment Process, Third International Symposium and Exhibition on Environmental Contamination in Central and Eastern Europe, Warsaw, 1996

2. CHMIELEWSKI A.G., ILLER E., ZIMEK Z., LICKI J., Laboratory and Industrial Research Installations for Electron Beam Flue Gas Treatment, Institute of Nuclear Chemistry and Technology - Warsaw, and Institute of Atomic Energy - Otwock, Poland, IAEA-SM-325/125

3. CHMIELEWSKI A.G., TYMINSKI B., ILLER E., ZIMEK Z., AND LICKI J., Electron Beam Flue Gas Treatment Process Upscaling, Environmental Applications of lonizing Radiation, John Wiley \& Sons, Inc., 1998

4. HIDEKI NAMBA, EB Treatment of Flue Gases, Department of Environment and Resources, Takasaki Radiation Chemistry Research Establishment, JAERI, Japan, 1993

5. TANAKA T., NAMBA H., AND DOI Y., The Proceedings of Mie International Forum, 1994

6. NAMBA H., et al., The Proceedings of the 3rd International Symposium on Advanced Nuclear Energy Research, 1991

7. ALBERTINSKY, B.I., High Voltage Electron Accelerators for Radiation Technology. The Main Characteristics, The Design of Accelerators and Their Elements, Training Course on Low Energy Accelerators and Their Applications, Leningrad, USSR, 1988.

8. CHMIELEWSKI, A.G., et al., The Double Window for Electron Beam Injection into The Flue Gas Process Vessel, Radiation Phys. Chem. Vol. 45, No. 6, 1995 